\title{
ArcheoSciences
}

Revue d'archéométrie

\section{Observations and questions on gold artefacts from underwater excavations}

The view of an archaeologist-restorer working in situ

Observations et interrogations sur des objets en or provenant de fouilles

archéologiques sous-marinesLe point de vue d'un archéologue-restaurateur

travaillant in situ

\section{Olivier Berger}

\section{(2) OpenEdition}

Journals

Electronic version

URL: https://journals.openedition.org/archeosciences/2494

DOI: $10.4000 /$ archeosciences. 2494

ISBN: 978-2-7535-1598-7

ISSN: 2104-3728

\section{Publisher}

Presses universitaires de Rennes

\section{Printed version}

Date of publication: 31 December 2009

Number of pages: 383-387

ISBN: 978-2-7535-1181-1

ISSN: $1960-1360$

\section{Electronic reference}

Olivier Berger, "Observations and questions on gold artefacts from underwater excavations",

ArcheoSciences [Online], 33 | 2009, Online since 10 December 2012, connection on 31 January 2022.

URL: http://journals.openedition.org/archeosciences/2494 ; DOI: https://doi.org/10.4000/

archeosciences. 2494 


\title{
Observations and questions on gold artefacts from underwater excavations
}

\section{The view of an archaeologist-restorer working in situ}

\author{
Observations et interrogations sur des objets en or \\ provenant de fouilles archéologiques sous-marines \\ Le point de vue d'un archéologue-restaurateur travaillant in situ
}

\author{
Olivier BERGER*
}

\begin{abstract}
In the present paper, we will study examples of settlement excavations that can sometimes reveal abundant gold material. These underwater excavations took place in Alexandria and Aboukir Bay, Egypt, where we found numerous gold or gold-plated objects. Of these, some objects provide us with information about the trade routes used in those times, and others show us that refinement existed even during the Byzantine period. Some objects tell us fabulous stories, while others attest a high mastery of the available technology.

Through specific examples, we will approach the scientific, aesthetic, historical and technological aspects pertaining to these gold objects.

While most of these gold objects, jewellery and coins, have been studied before, and the results published elsewhere, considering the number of excavated objects, it is typically the less spectacular ones or the ones that were too difficult to interpret that have been neglected.

Being an archaeologist specialised in the restoration of metal, I am thus not a metallurgist, a technologist, or even a numismatist, nor a historian specialised in the production or trade of gold objects. However, on the boat, underwater, or in the land laboratory, many questions concerning these archaeological objects deserve attention.

With the help of three case studies, we will see that some problems related to these objects have come up, and that a close collaboration with various gold artefact specialists appears necessary in order to try to solve these uncertainties.

Résumé : Seront abordés des exemples de fouilles d'habitats qui parfois peuvent livrer un abondant matériel en or. Ces fouilles sous-marines, sont menées en Egypte, à Alexandrie et Aboukir. Lors de nos campagnes de fouilles, nous avons trouvé de nombreux objets en or ou recouverts d'or. Certains objets nous parlent des voies commerciales, certains nous démontrent un raffinement d'une période dite décadente. D'autres objets nous racontent de fabuleuses histoires, d'autres encore sont des preuves d'une haute maîtrise technologique.

Au travers de quelques découvertes, nous allons approcher l'aspect scientifique, esthétique, historique et technologique de ces objets d'or.

Si la majorité des objets, monnaies ou bijoux, sont étudiés et publiés étant donné la masse de documents exhumés, il en est de moins spectaculaires et de plus délicats à interpréter qui sont délaissés.

Etant un archéologue spécialisé dans la restauration du métal, je ne suis donc ni analyste, ni métallurgiste, ni technologue, ni numismate, ni non plus un historien spécialiste de la production, du commerce ou de la circulation des objets en or, et pourtant, que de questions se posent face à ces objets archéologiques trouvés lors de fouilles et restaurés in situ.

A travers trois cas, sera entrevue une base d'étude où seule une collaboration pluridisciplinaire pourrait répondre aux problématiques posées.
\end{abstract}

Keywords: FTIR, Egypt, goldsmith, gold-working, metal restoration, underwater archaeology.

Mots-clés : FTIR, Égypte, orfevre, travail de l'or, restauration du métal, archéologie sous-marine.

${ }^{*}$ Conservateur-restaurateur au musée des Antiquités de Bâle - 5, St. Alban-Graben, 4051 Bâle, Suisse. (bergoliv@hotmail.com) 


\section{INTRODUCTION}

The methods employed by the ancient Egyptian goldsmiths have been covered in some detail elsewhere, although there is still a need for a far more comprehensive study (Ogden, 2000: 164).

The European Institute of Underwater Archaeology (Institut européen d'archéologie sous-marine, IEASM) led by Franck Goddio, has been carrying out excavations in Egypt for more than ten years. We are working in the Nile Delta, and more precisely in Alexandria and Aboukir Bay, where, under the sea, we found the remnants of the sunken cities of Canopus and Heracleion. More than 15,000 artefacts were discovered at these sites, and, among this abundant material, we mainly found stone work. However, we also found objects made of organic material, ceramic, glass, and different metals. Some rare objects made of silver and those made of iron generally disappear in the sea water environment, but bronze, lead and gold objects are frequently discovered.

What is unusual about these sites is that they were abandoned because of several natural cataclysms and not reoccupied during the last centuries. That is why we had the chance to find many intact artefacts, such as ritual dishes, which are rather infrequent in other excavations.

The corpus of gold artefacts is mainly represented by jewellery and gold coins, originating mostly from the Ptolemaic and Byzantine periods. The jewellery is relatively standard, and it includes rings, earrings, beads, pendants, and pendants with some gem stones (amethyst, emerald, sapphire, garnets), glass, or pearls. Several rings are delicate and some are made of massive beaded wires. Some of them are without decoration or with just one gem, but some others are finely decorated and show scenes of everyday life.

Through specific examples, we will approach the scientific, aesthetic, historical and technological aspects pertaining to these gold objects.

\section{Methods $\$ 1$}

Some rings show interesting stories, like a romantic Byzantine wedding ring originating from Canopus and dating from the $6^{\text {th }}$ or $7^{\text {th }}$ century AD (Fig. 1). The translation of the Greek inscription engraved inside the ring reads "Peace, which is mine, I give it to you. Amen". This citation is from the Gospel of John $(14,27)$. There are, interestingly, two orthographic mistakes in this sentence.

The face of the ring bears the inscription OMONOIA, which means 'union' (Lat. 'concordia'), as was traditionally
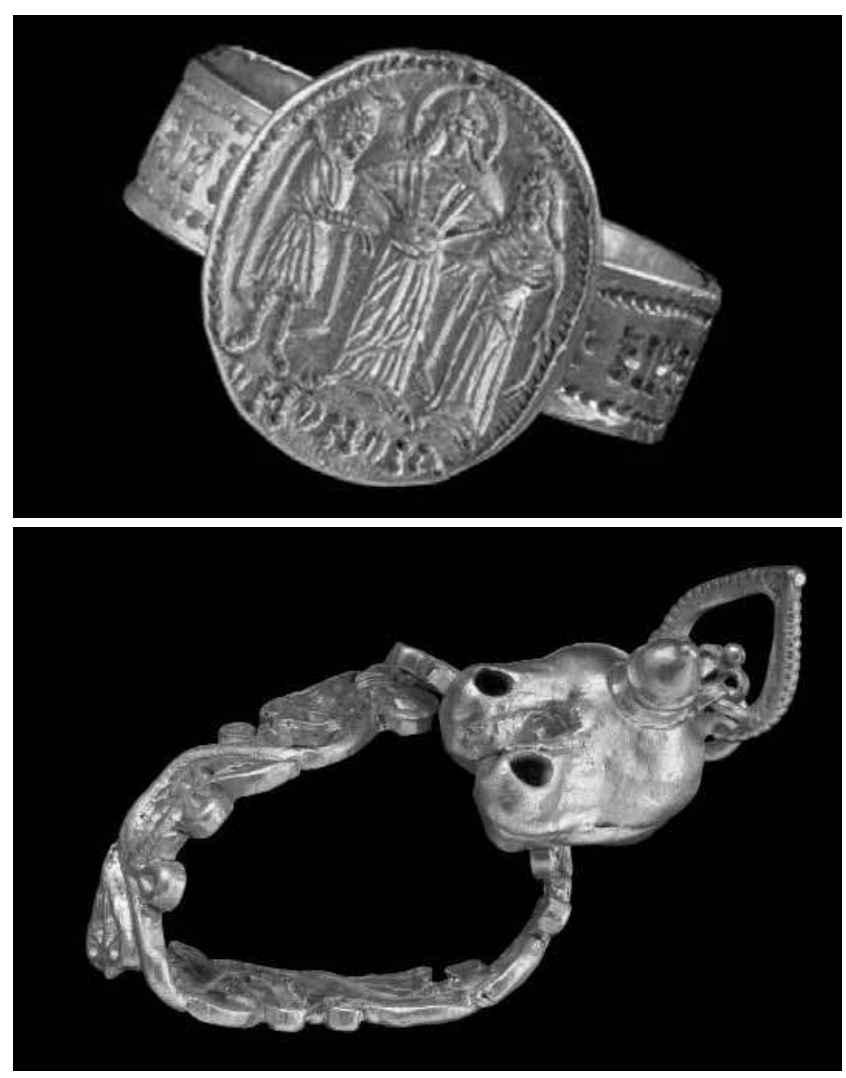

Figure 1: Wedding ring and ring with a bezel in the shape of an oil lamp.

Figure 1: Bague de mariage et bague avec un chaton en forme de lampe à huile.

written on wedding rings at that time. OMONOIA was an inscription chosen by Christians in reference to the first word of verse 16 of chapter 25 in the book of Sirach, which deals with marital and family relationships: "The Union of brothers, the friendship of neighbours, and wife and husband living in perfect harmony" (Tardieu, 2006).

The Byzantine period is nicely represented by a fine handicraft ring with a bezel in the shape of an oil lamp (Fig. 1). The details are so perfectly made that the top lid can still be moved. Found on the site of Canopus, this ring is dated to a period between the end of the $6^{\text {th }}$ and the beginning of the $7^{\text {th }}$ century AD. This type of ring seems unique, as we could not identify any parallels to it, and only its decorative waves and vegetal ornament can be compared to those of the ring found in the treasure of Pantalica, Sicily (Stolz, 2006).

An important discovery was made at the site of Heracleion in 2003, when we found a gold plaque with inscriptions. Unfortunately, it was not in its original position but at the bottom of a canal. The object is $5 \mathrm{~cm}$ high, $10.8 \mathrm{~cm}$ wide and $0.8 \mathrm{~cm}$ thick. Written in Greek, this gold plaque was 
made to celebrate the construction of a monument (gymnasium) by Ptolemy III. In 1818, a 6 by $6 \mathrm{~cm}$ gold blade was found in Aboukir; it is also engraved in Greek, and it is currently in the British Museum ( $\left.\mathrm{N}^{\circ} 1063\right)$. The plaque bears the dedication of a Temenos to Osiris in the name of Ptolemy III and Berenice II (Yoyotte, 2006; Clauss, 2006).

Sometimes, gold objects can be of help in understanding the trade between Egypt and other countries. The Hemistater of Pumiyaton is an artefact originating from Cyprus, with a naked walking Heracles wearing only his traditional lion skin. It dates from the $4^{\text {th }}$ century BC. An unusual aspect of the representation in this object is the fact that Heracles is beardless. The reason for this is that the Cypriot Herakless-Melquart is not heavily bearded, like the classical one. On the reverse, a Phoenician inscription with the name of the king Pumiyaton dates the issue to the seventh or eighth year of his reign (355/353 BC) (Yoyotte, 2006; Lichocka, 2006).

An object that is very interesting from a technological point of view is a gold eye of Horus (Wedjat) found in Heracleion (Fig. 2). This bead, hollow inside, is made of two gold blades and a strip of gold sheet used for the sides (Stolz, 2006). We can put forth a hypothesis regarding the technique used to make the pupil, using a flat sphere, filigree and granulation for the decoration. This object is really small, measures $8 \mathrm{~mm}$ and weighs $0.4 \mathrm{~g}$; it is less than $2 \mathrm{~mm}$ thick. It makes us wonder how the ancient craftsmen were able to weld all those small pieces together, and to produce such tiny details. Usually, this type of jewellery is embossed or moulded, and it is quite unusual to identify the use of filigree and granulation, indicating the intricate work involved in the production of such a small object.

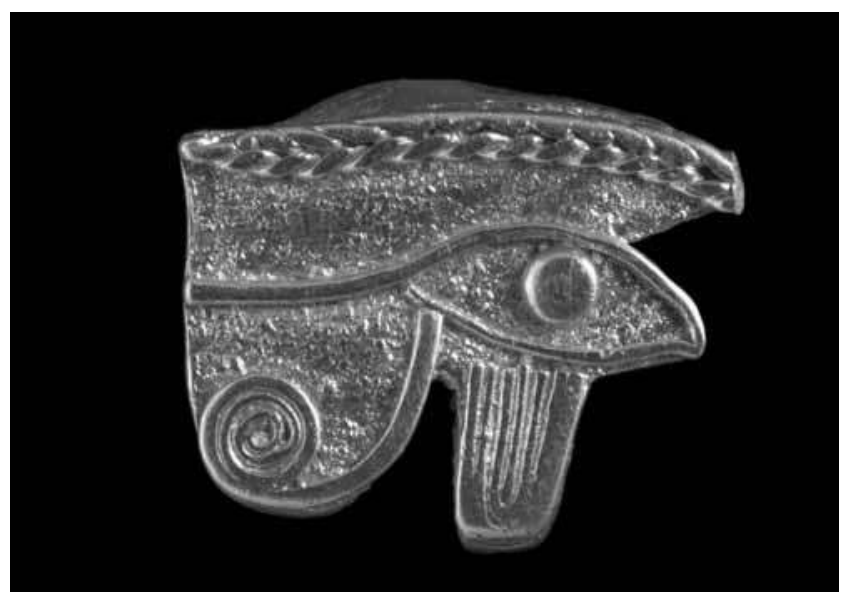

Figure 2: Gold eye of Horus (Wedjat).

Figure 2 : Cil d'Horus (Oudjat).

\section{Methods $\$ 2$}

On the boat, underwater or in the land laboratory, many questions concerning archaeological objects arise, and even a simple object can provide significant information, but also bring about numerous other questions.

Case 1 - The most interesting questions that arise from our research concern a carved limestone deposit holding more than one kilogram of gold leaves. A hard black substance was found among the gold leaves. After microchemistry tests carried out at the Expert Center laboratories in Lausanne, we established that it was an organic substance, and after analyses with FTIR (Fourier Transform Infrared Spectrometry) and GC-MS (Gas Chromatography - Mass Spectrometry), we were able to determine that it was a natural resin like rosin with what appear to be traces of perfume rosin, like myrrh or aloe vera. The gold foil does not have a regular size, but displays a constant layer thickness of $12.3 \pm 0.9 \mu \mathrm{m}$, almost comparable to chocolate paper. The examination of the gold composition by XRF (X-ray Fluorescence Spectrometry) and AAS (Atomic Absorption Spectrometry), carried out at the research laboratory of the Swiss National Museum, provided us with the composition of the metal. The gold contains silver, platinum and iron, but no copper (Table 1).

Does this information allow us to infer that it was used in a temple as an offering to the gods, with gold and perfume resin, or that it was some type of offering deposited in the foundation wall during the construction of an important building, like a foundation deposit? Is it possible that it was hidden by a goldsmith, and that the metal was meant to be melted again, or that it was a sort of kit for gilding, with the resin used as glue? As mentioned in the literature (Higgins, 1961; Pliny the Elder, 1983), it was not unusual to find this thickness for a gold leaf, but the question still remains concerning the kind of material that this type of gold leaf was meant to gild: stone, metal or wood?

Case 2 - Gold is stable even underwater; however, in land excavations, the fragments of gold artefacts or even small objects are mixed with sediment. In such cases, gold starts to tarnish and we cannot easily distinguish it from other materials or sediments. On the other hand, gold is not altered in sea water; in Nile clay, in sand or other sediments, gold preserves its shiny metal reflection. The objects are so shiny and dense that they can be seen immediately in the sediment or in the sifter discarded by the water dredge. That is why, in the context of our work, we found a considerable amount of small pieces of gold and elements of goldsmithing, a less common phenomenon in land excavations. 


\begin{tabular}{|c|c|c|c|c|c|c|c|}
\hline Denomination & \% Sn & \% Pb & \% As & \% Sb & \% Pt & \% Ti & \% Ag \\
\hline Gold sample & $<0.0010$ & 0.0006 & $<0.0010$ & $<0.0010$ & 0.0202 & $<0.0020$ & 0.1741 \\
\hline
\end{tabular}

\begin{tabular}{|c|c|c|c|c|c|c|}
\hline$\% \mathbf{~ N i}$ & \% Bi & \% Co & \% Zn & \% Fe & \% Cu & $* \% \mathbf{A u}$ \\
\hline 0.0007 & $<0.0010$ & $<0.0010$ & $<0.0010$ & 0.0176 & 0.0025 & 99.7843 \\
\hline
\end{tabular}

*\% Au: The gold composition has been calculated (100\% - total composition of trace elements)

Table 1: Composition of the gold leaves.

Tableau 1 : Composition des feuilles d'or.

We can focus on two small representative deposits of gold fragments, one containing 63 gold pieces, and the other one 42 fragments. Having a closer look at the fragments, we can observe that they represent small pieces of objects, mostly jewellery. We can thus recognise fragments of objects, palmette-shaped appliqués, beads of different sizes and shapes, chain links, ornaments, earrings, parts of necklaces, bracelets, annuli, granules, pendants, wires, etc. The question that arises is: did they break naturally, were they there to be melted, or were they intentionally broken to be offered to the gods and then spread onto the land?

In the area of one temple, we found many small factice offerings of lead coins, thousands of them. This finding conveys perhaps a similar phenomenon: instead of offering jewellery, ancient people sometimes preferred to offer a large amount of precious metal - but in small fragments.

Case 3 - Very often, we see that Egyptian archaeological bronze sculptures have been gilded and we can observe traces of gold or technological details employed in the gilding preparation.

A crown found in Heracleion, from a life-size statue, has a roughened surface with a lot of cross hatchings made with gravers or burins; however, we could not find any trace of gold on it. It is not rare in Egypt to find bronze sculptures overlaid with gold, using the technique of roughening by stippling or chiselling the surface in order to facilitate the adhesion of the gold leaf to the copper alloy (Oddy et al., 1988). This strong and thick gilding requires different layers of gold leaves to cover the cross hatching. In some cases, a mineral preparation is carried out between the two metals (Oddy, 1981). On the other hand, some objects are perfectly polished and gilded, and in many cases we can still observe the gold leaves. The fire gilding, using mercury-gold amalgam, was unknown prior to the Ptolemaic period (Ogden, 2000); other methods were used instead.

In the research laboratory of the Swiss National Museum, we analysed a Mummiform Osiris found in Heracleion. This sculpture has a gold blade inlay for the eyes and is overlaid with extremely thin gold leaves on the body. The antique surface was polished without any intentional engraving. It seems that there was a resin or a drying oil between the metal and the gold leaves. In seawater, an organic material like resin can be well preserved. The analyses were performed to see if we could recognise what type of medium they used to attach the gold leaves. This method has been attested in Egypt since the third millennium BC (Raub, 1993). Unfortunately, the result was negative and we were not able
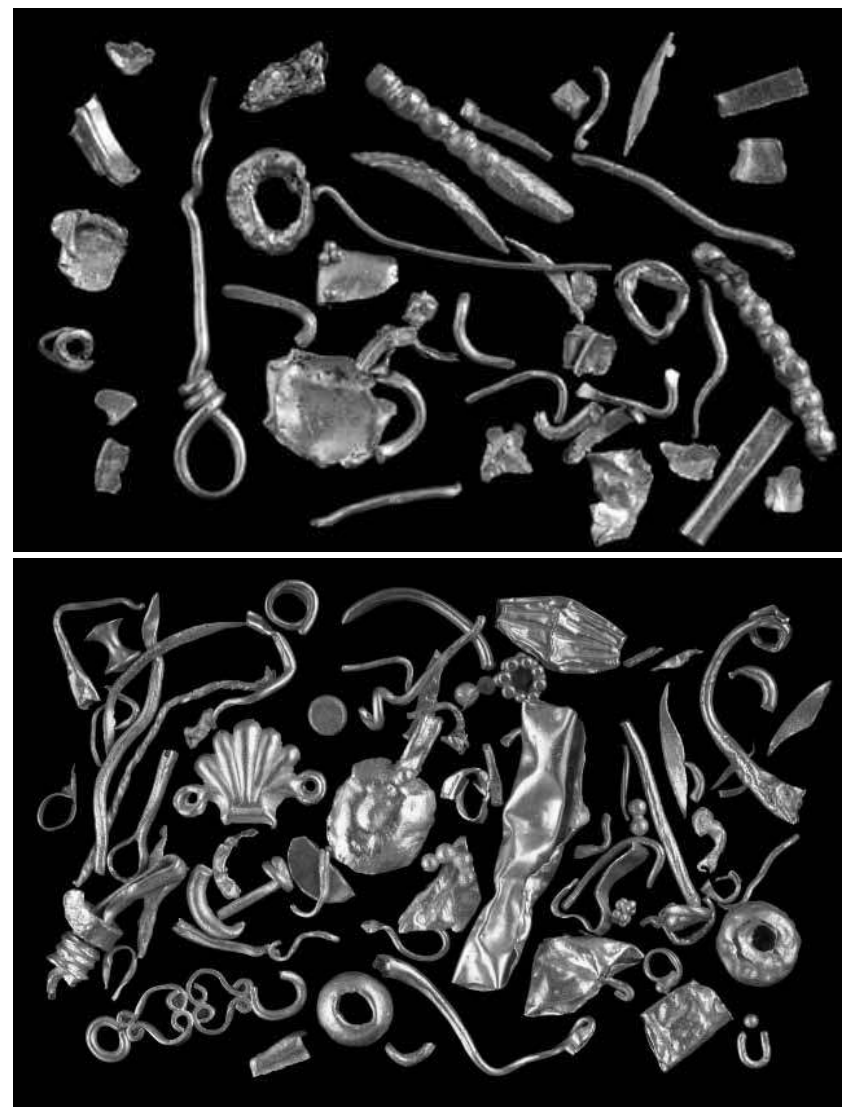

Figure 3: Deposit of gold fragments.

Figure 3 : Dépôt de fragments d'or. 
to find any organic component, only gold and products from the corrosion of the bronze.

Can this be an indication that the gold leaves can stick directly to the metal without any preparation, just with heat and strongly burnished? As we know from literary sources, this technique seems to have been attested in Egypt since the second millennium BC (Oddy, 1982). However, specialists do not agree on this subject (Ogden, 2000).

The ancient artists were able to cast a life-size sculpture in bronze, to polish its surface, to chisel all the details, and, after they spent a significant number of hours only to scratch, to hatch and engrave the nice skin of the sculpture, they would disfigure it for the only purpose of having a terribly roughened surface. This method, entailing creation followed by destruction, must have had a higher purpose.

However, if they were able to simply apply the gold leaf directly on the polished metal surface, with a very nice result and while using less gold, being faster and requiring less preparation, the question is why, in the same period, in the same place, on the same bronze support, for the same object, would they have used different methods for gilding? On an object like an Osiris, they used two different types of gold: one for gilding with very thin gold leaves, the other, using thick gold blades, for inlaying the eyes. Thus, we can observe, on the same object, the use of gold blade and gold leaves without resin, and a roughened surface, carried out during the same period, at the same archaeological site, and even in the same temple. Then, the question of why so many different techniques were used remains open.

\section{Conclusion}

As archaeologists, we do not find many gold objects on our excavations; as restorers specialised in metal, we do not have to perform many interventions on stable gold objects, but, however, we come across many questions and there is so much information to obtain from these small precious objects.

Sometimes, as restorers, we enjoy the privilege of having access to some technological details and useful information. We spend so many hours working on and with the objects that we come to know them very closely. For example, we can observe gold traces in the corrosion products which will disappear during the restoration treatment. However, if we have this privilege, we also have the responsibility to describe and to document our observations. Most of the time we do our best, but we are not specialized in archaeological gold objects and we sometimes overlook certain technological knowledge pertaining to them. We lack reference articles and one cannot help but notice that we are in need of a more close collaboration with specialists and experts.

\section{Acknowledgements}

Hildebrand Erwin, Chemistry scientist, Swiss National Museum. Hunger Katja, Chemistry scientist, Swiss National Museum. Chartier-Raymond Maryvonne, Egyptologist. Samson Guylaine, Translation. Soares-Woerle Marie, Head of the research laboratory of the Swiss National Museum. WichgersDraganski Anka, Dr. in Archaeology.

\section{References}

Higgins, R.A., 1961. Greek and Roman Jewellery, London: Methuen.

Clauss, M., 2006. Gold for the house of gods. Ptolemy III foundation plaque, in Franck Goddio, Manfred Clauss (eds.), Egypt's Sunken Treasures, Munich and London, Prestel, 140.

Liсноска, B., 2006. Cypriot hemistater, in Franck Goddio, Manfred Clauss (eds.), Egypt's Sunken Treasures, Munich and London, Prestel, 351.

ODDy, W.A., 1981. Gilding through the Ages, Gold Bulletin 14: 75-79.

ODDY, W.A., 1982. Gold in Antiquity: aspects of gilding and of assaying, Journal of the Royal Society of Arts, 5315 (130): 730-743.

Oddy, W.A., Pearce, P. and Green, L., 1988. An unusual gilding technique on some Egyptian bronzes, in S.C. Watkins and C.E. Brown (eds.), Conservation of Ancient Egyptian Materials, Conference Proceedings, Bristol, 15-16 December 1988, London, United Kingdom Institute for Conservation, Archaeology Section, 35-39.

Ogden, J., 2000. Metals, in P.T. Nicholson, I. Shaw (eds.), Ancient Egyptian Materials and Technology, Cambridge, Cambridge University Press, 148-176.

Pline L'Ancien, [1983]. Histoire naturelle, livre XXXIII, chap. XIX, $\$ 61$.

Raub, C., 1993. How to coat objects with gold, in C. Eluère (ed.), Outils et Ateliers d'Orfevres des Temps anciens, Saint-Germainen-Laye, Antiquités Nationales, mémoire 2, 101-110.

sToLz, Y., 2006. Styles in early byzantine gold jewellery and the bead in the shape of an eye of hours or wedjat, in Franck Goddio, Manfred Clauss (eds.), Egypt's Sunken Treasures, Munich and London, Prestel, 212 and 316.

TARDIEU, M., 2006. Wedding ring, in Franck Goddio, Manfred Clauss (eds.), Egypt's Sunken Treasures, Munich and London, Prestel, 300.

Yoyoтte, J., 2006. Herakles, a man of mighty deeds, forever questing for proofs of his courage and Ptolemy III foundation plaque, in Franck Goddio, Manfred Clauss (eds.), Egypt's Sunken Treasures, Munich and London, Prestel, 72 and 140. 
